\title{
Ice-flow stages and glacial bedforms in north central Ireland: a record of rapid environmental change during the last glacial termination
}

\author{
A. MARSHALL McCABE, JASPER KNIGHT \& STEPHEN G. McCARRON \\ School of Environmental Studies, University of Ulster, Coleraine, Co. Londonderry BT52 ISA, UK \\ (e-mail:m.mccabe@ulst.ac.uk)
}

\begin{abstract}
Satellite imagery is a useful tool to assess large-scale $\left(>10^{3} \mathrm{~km}^{2}\right)$ geological patterns. Satellite imagery of north central Ireland shows cross-cut and overprinted subglacial bedform patterns. Bedform lineations, supported by sedimentary evidence, are used to reconstruct four ice-flow stages (named A-D) during the termination of the last (Devensian) glaciation $\left(22000-13000\right.$ radiocarbon $\left({ }^{14} \mathrm{C}\right)$ years $\left.\mathrm{BP}\right)$.

Flow stage A relates to southwesterly flow of Scottish ice across eastern Ireland. Flow stage B, during the last glacial maximum (c. $25000-22000{ }^{14} \mathrm{C}$ years BP), records southeasterly ice-flow from dispersal centres in northern parts of Ireland. Transverse subglacial ridges (Rogen moraines) formed during stage $\mathrm{B}$ are the largest area of this ridge type in western Europe. Flow stage $\mathrm{C}$ records erosional headcutting in the Rogen moraine field and sediment streamlining (drumlinization) by ice streams drawn into the Irish Sea Basin. This flow stage is constrained by AMS radiocarbon dates from marine microfaunas to around $14500{ }^{14} \mathrm{C}$ years BP. Flow stage D records drumlinization from an inland centre in the Lough Neagh Basin.

Overall bedform patterns can be used to reconstruct ice mass history and evaluate controls on ice activity, including millennial-scale changes in amphi-North Atlantic climate. Field evidence of bedform relationships also casts doubt on current concepts of drumlinization and the role of pervasive sediment deformation in glacial systems.
\end{abstract}

Keywords: Ireland, glacial sedimentation, drumlins, ice streams, bedforms.

Remotely-sensed images of glaciated landscapes record complex subglacial bedform patterns on different scales (e.g. Punkari 1985, 1993; Boulton \& Clark 1990; Clark 1993). Meso-scale bedform patterns $\left(<10^{3} \mathrm{~km}^{2}\right)$ have been used to investigate the origins of individual bedform types such as drumlins (Patterson \& Hooke 1995) and Rogen moraines (Bouchard 1989; Fisher \& Shaw 1992). Patterns of mega-scale $\left(<10^{5} \mathrm{~km}^{2}\right)$ lineations have been used to reconstruct the history of large ice sheets (Punkari 1985; Boulton \& Clark 1990; Clark 1993). Evidence for millennial-scale shifts in the coupled ice-ocean-atmosphere system during the late Devensian (Wisconsinan) (Bond \& Lotti 1995; Manabe \& Stouffer 1995) suggests that the formation of meso- and mega-scale lineations may be related to changes in basal ice conditions during periods of climate system reorganization. These ideas can be tested in glaciated landscapes when regional ice flow patterns can be identified and their relative chronology established. Time-constrained reconstructions of ice-mass history are possible when the relative flow chronology can be related directly to other known events, such as ice readvances and ice-marginal stratigraphical markers such as datable marine beds (McCabe 1996) and glaciotectonically thickened sediment wedges (Eyles \& McCabe 1989). All dates given here are in ${ }^{14} \mathrm{C}$ years BP unless stated otherwise.

\section{Rapid environmental change}

Glacial bedforms found near the former margins of the last British ice sheet can be best explained by rapid environmental changes during episodes of ice activity (McCabe 1996; Knight $\&$ McCabe $1997 a, b)$. However, variability in overprinted and cross-cut bedform signatures has not been formalized into recognizable shifts (stadials and interstadials) within the overall glacial cycle (McCabe \& Clark 1998). Current generalized ice-flow models (e.g. Boulton et al. 1977; Bowen et al. 1986) therefore mask major regional changes in ice-mass dynamics in key areas such as around the margins of the Irish Sea Basin. Recent results from satellite imagery analysis and AMS ${ }^{14} \mathrm{C}$ dating of marine microfaunas suggest that glaciogenic deposits in this area reflect millennial-scale ice mass oscillations, shifts in ice divide locations and major changes in flow direction (McCabe 1996; Knight \& McCabe 1997a, b; McCabe \& Clark 1998). Older ice flow lineations may be preserved only if they are not completely modified morphologically by later ice events. Bedform preservation potential is also enhanced in marginal zones due to changes in ice margin configuration, basal thermal regimes and ice flow dynamics.

\section{Study area}

Landsat Thematic Mapper (TM) imagery (spatial resolution of about $30 \mathrm{~m}$ ) is suitable for evaluating ice dynamics and bedform evolution in the north central Irish lowlands (c. $15000 \mathrm{~km}^{2}$ ) during the late Devensian. This area, located south of the former main ice dispersal centres, occurs on the western margin of the Irish Sea Basin which was the most active conduit draining the last British ice mass (Eyles \& McCabe 1989) (Fig. 1 \& 2).

The overall aims of this study are to (1) describe the glacial bedforms of part of north central Ireland, and (2) reconstruct glacial events using regional bedform evidence supported by sedimentary data from specific localities (Fig. 3). The study area shows previously undocumented ice-flow-transverse ridges which are similar in scale and morphology to Rogen 


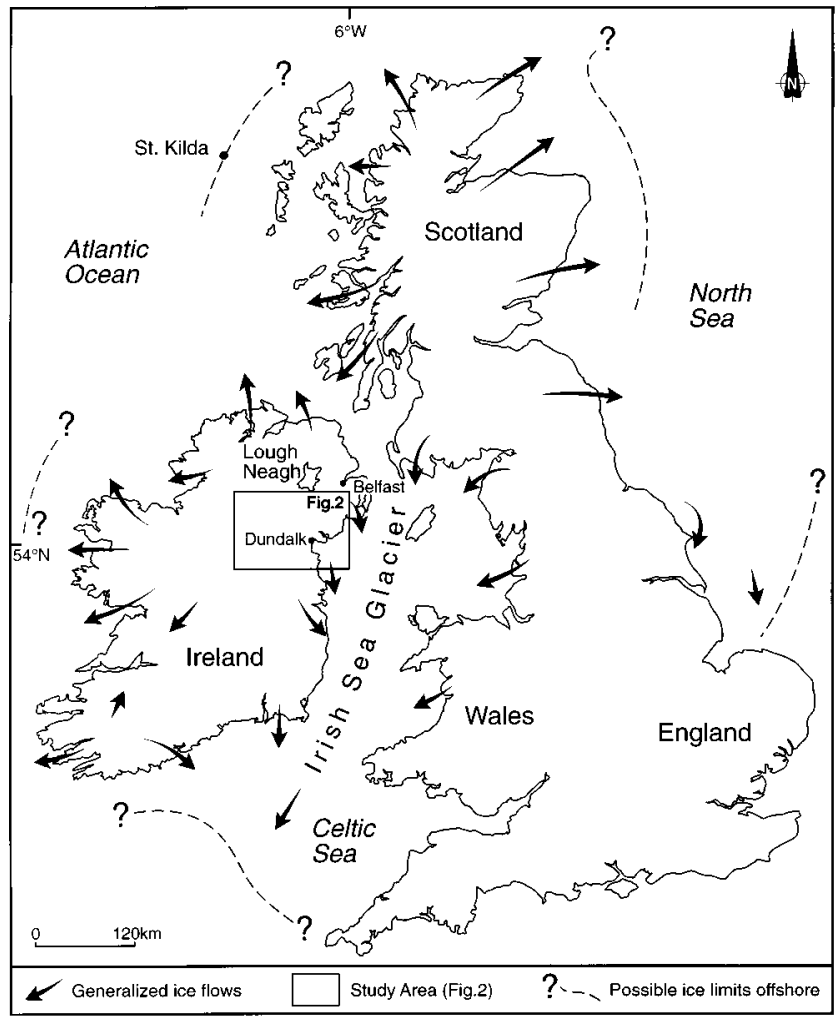

Fig. 1. Location of the study area in north central Ireland, possible offshore ice limits and generalized ice-flow lines for the late Devensian British ice sheet. Note that these flow lines (e.g. Boulton et al. 1977) mask regional-scale patterns of ice mass variability.

moraines, forming the largest region (total $>1500 \mathrm{~km}^{2}$ ) of this bedform type in western Europe (Knight \& McCabe 1997b) (Figs $4 \mathrm{a}, \mathrm{b} \& 5$ ). The overall pattern of transverse ridges and other ice flow lineaments contrasts markedly with recent maps of bedform alignment in north central Ireland which do not use primary field or satellite data (e.g. Warren 1992). These results suggest that Irish ice was highly dynamic and responsive to changes in environmental regimes in the northeastern Atlantic region.

\section{Glacial lineations and ice flow patterns}

From satellite imagery, bedforms identified in the study area include (1) large-scale ice-moulded bedrock scallops on isolated uplands, (2) flow-parallel streamlined rock ridges and sediment ridges, (3) flow-transverse ridges located within lowland basins, and (4) drumlins of various size and shape. Smaller scale sediment flutings $(<30 \mathrm{~m}$ size $)$ are not identified readily from satellite images but can be observed in the field as ornamentations on the larger bedforms. All major bedform patterns identified were confirmed in the field.

Spatially, glacial lineations showing a consistent directional signature are grouped into four major flow stages (A-D) (Fig. 3). The relative chronology of each flow stage is evaluated on the basis of bedform alignment, location, morphological attributes and overprinted or cross-cutting relationships. Field characteristics of each flow stage are supplemented by regional geological data in order to explain ice mass sources, changes in ice flow direction and thermal regime, and variations in ice dynamics. Site-scale sedimentary evidence for individual flow stages is described elsewhere (e.g. McCabe 1972, 1973, 1987; Dardis 1982; Eyles \& McCabe 1989; McCabe \& Dardis 1989; Knight \& McCabe 1997a).

\section{Flow Stage A}

Northeast-southwest aligned bedrock ridges (covering an area of $\left.180 \mathrm{~km}^{2}\right)$ are cut into steeply dipping $\left(<80^{\circ}\right)$ Silurian greywackes near Crossmaglen (Fig. 4a). Typically, bedrock ridges (0.20-0.75 km long, 5-20 m wide, 3-6 m high) are confined to topographic lows between larger diamict-dominated drumlins whose crests rise $20-30 \mathrm{~m}$ above the highest bedrock ridges. At specific sites bedrock ridge alignment deviates by as much as $40^{\circ}$ from local bedrock strikes $\left(10-40^{\circ}\right)$. At Annaghmore (Fig. 4a) asymmetric roches moutonnées ( $<2 \mathrm{~m}$ high) have been bevelled by ice along their mid-stoss slopes. Curved glacial gouges (1.0-1.5 m long, $2 \mathrm{~cm}$ deep) are present on the stoss slopes of two roches moutonnées and record ice flow from the northeast. The relatively fresh nature of these features does not suggest they belong to an earlier glacial event.

No glacigenic diamicts (tills) have been found associated with the bedrock ridges around Crossmaglen, but regional evidence shows that southwesterly ice advance from the Irish Sea Basin deposited diamicts and carried erratics onto the northeastern Ireland seaboard (Dwerryhouse 1923; Charlesworth 1939; Synge \& Stephens 1960) (Fig. 3). Chalk, flint and Ailsa Craig microgranite erratics were reworked in basal diamicts deposited by later southeasterly-flowing ice (flow stages B and C) (McCabe 1972). A similar stratigraphical sequence is present in the Boyne Valley where 'shelly tills' deposited by Irish Sea Basin ice (McCabe 1972) are associated with northeast-southwest striations and occur below glacial diamicts of flow stage B (Fig. 3). We therefore conclude that Irish Sea ice (flow stage A) advanced at least $60 \mathrm{~km}$ inland from the present coast, covering much of north central Ireland. Flow stage A ice dispersal patterns suggest that a major ice centre was located in southwestern Scotland, $250 \mathrm{~km}$ to the northeast.

\section{Flow Stage B}

Four independent sets of directional indicators suggest unrestricted southeastward ice flow towards the Irish Sea Basin from centres in north central Ireland (Fig. 3).

Tyrone Igneous Complex erratics were transported east and southeastwards into the Lough Neagh Basin prior to ice flow stage C. Dardis (1982) demonstrated that this erratic spread was later reworked into drumlin diamicts by westward and northward-going ice from the Lough Neagh Basin (ice flow stages $\mathrm{C}$ and $\mathrm{D}$ ). It is therefore probable that primary dispersal of erratics took place during flow stage B.

Large-scale ice-moulded bedforms of a scallop shape are present on the summit of Slieve Beagh and record southeasterly ice flow from the Omagh Basin (Fig. 5). These forms are cut into flat-lying Carboniferous sandstones and have a rounded morphology with convex stoss and concave lee slopes and horns which trend towards the southeast. The scallops have a nested pattern, occur generally above $150 \mathrm{~m}$ oD, range in height from 30 to $40 \mathrm{~m}$ and have a wider cross profile $(<1 \mathrm{~km}$ across) than long profile. Scallops also show icepolished surfaces with northwest-southeast oriented striations, especially in the western side of the Slieve Beagh massif (McCabe 1969) (Fig. 3). 


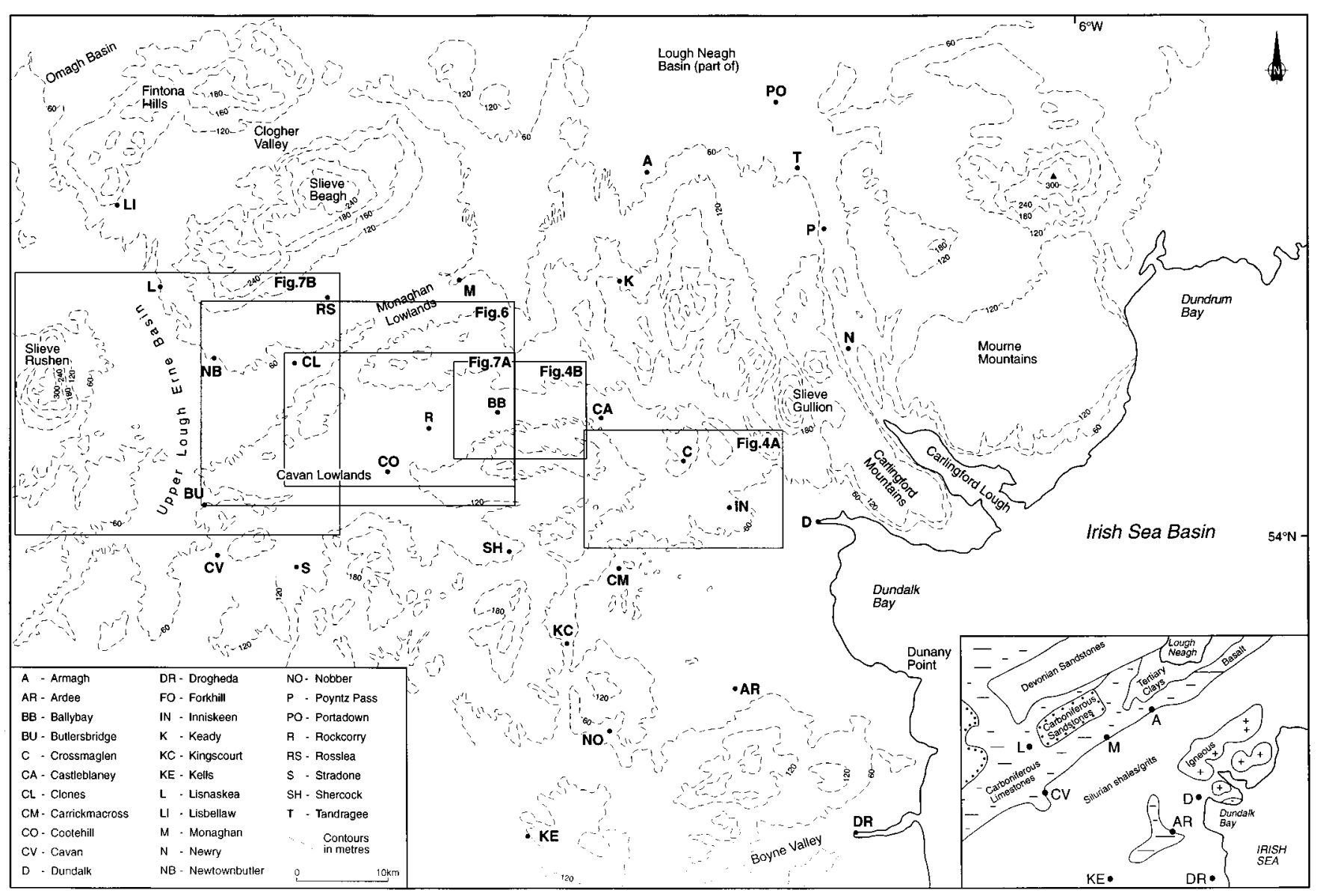

Fig. 2. Topography of north central Ireland and locations named in the text. Inset map shows the general geology.

The area around Upper Lough Erne, Cavan and Monaghan $(<130 \mathrm{~m} \mathrm{OD})$ is dominated by closely-spaced north-eastsouthwest-trending sediment ridges (Fig. 5). Around Keady, Ballybay and Carrickmacross this directional grain is cut out cleanly by a later ice flow (flow stage C) (Fig. 3). The same ridge morphology is also present around Tandragee (Fig. 5). Ice-moulded bedrock ridges aligned northwest-southeast occur on the southern margins of, and within, the northeastsouthwest sediment ridge zone around Stradone (Fig. 5). Erosional marks on bedrock ridges record a regionally consistent northwest-southeast ice-flow pattern (Fig. 3) to which the sediment ridges lie transverse. This close field association suggests strongly that both ridge types are related genetically to the same southeasterly ice flow.

Most transverse ridges (spaced 1.5-2.0 km apart) are slightly sinuous, vary between 1 and $5 \mathrm{~km}$ in length (occasionally up to $10 \mathrm{~km}$ ), with straight to undulating crestlines (Figs 6 \& 7a). Generally, smaller ridges possess linear and rounded crestlines whereas larger ridges show variable crestlines with shallow undulations $(5-10 \mathrm{~m})$ and occasional deeper saddles $(<20 \mathrm{~m})$. Local ridge heights are highly variable $(15-35 \mathrm{~m})$ and summits are not accordant. Ridge cross-profiles are often strongly asymmetric with steeper facing northwestern (stoss) slopes. Around Rockcorry, Cootehill and Ballybay individual ridges show a strong topographic grain unrelated to the strike of the underlying bedrock (Fig. 6 \& 7a). Ridges around Upper Lough Erne are less well organized, have more intricate plan geometries and determine present drainage and lake outlines (Fig. 7b).
Small $(<4 \mathrm{~m}$ high) field sections suggest that transverse ridges are composed mainly of coarse and poorly sorted massive diamict. In all cases sediments contain a high proportion (around 70\%) of freshly quarried, angular local bedrock clasts. Larger $(2-3 \mathrm{~m})$ erratics are also present. The origin of these sediments cannot be evaluated precisely on the basis of exposure size. However, the scale of the lineation grain, together with associated ice moulding and striation patterns and the above limited sedimentological evidence, suggests a subglacial origin. Additionally, overall plan geometry and individual ridge size and shape are similar to descriptions of Rogen moraines (Lundqvist 1969, 1989; Bouchard 1989; Fisher \& Shaw 1992).

Southeasterly ice flow associated with the transverse ridges and adjacent erosional marks is recorded around Drogheda by colinear striation and diamict clast fabrics (McCabe 1972, 1973) (Fig. 3). Stratigraphically these diamict facies overlie the 'shelly tills' deposited during flow stage A. The consistent northwest-southeast trend of both striations and diamict clast fabrics confirms that flow stage B ice moved southeastwards towards the Irish Sea Basin. Low variability of inland directional indicators, and the absence of shore-parallel striations at this stratigraphic level, suggests that regional deflection by a major Irish Sea Basin ice mass did not occur.

These lines of geological evidence consistently record southeastward stage B ice flow over at least $160 \mathrm{~km}$ from the Lower Lough Erne Basin into the Irish Sea Basin (Fig. 3). The absence of igneous erratics derived from central Donegal 


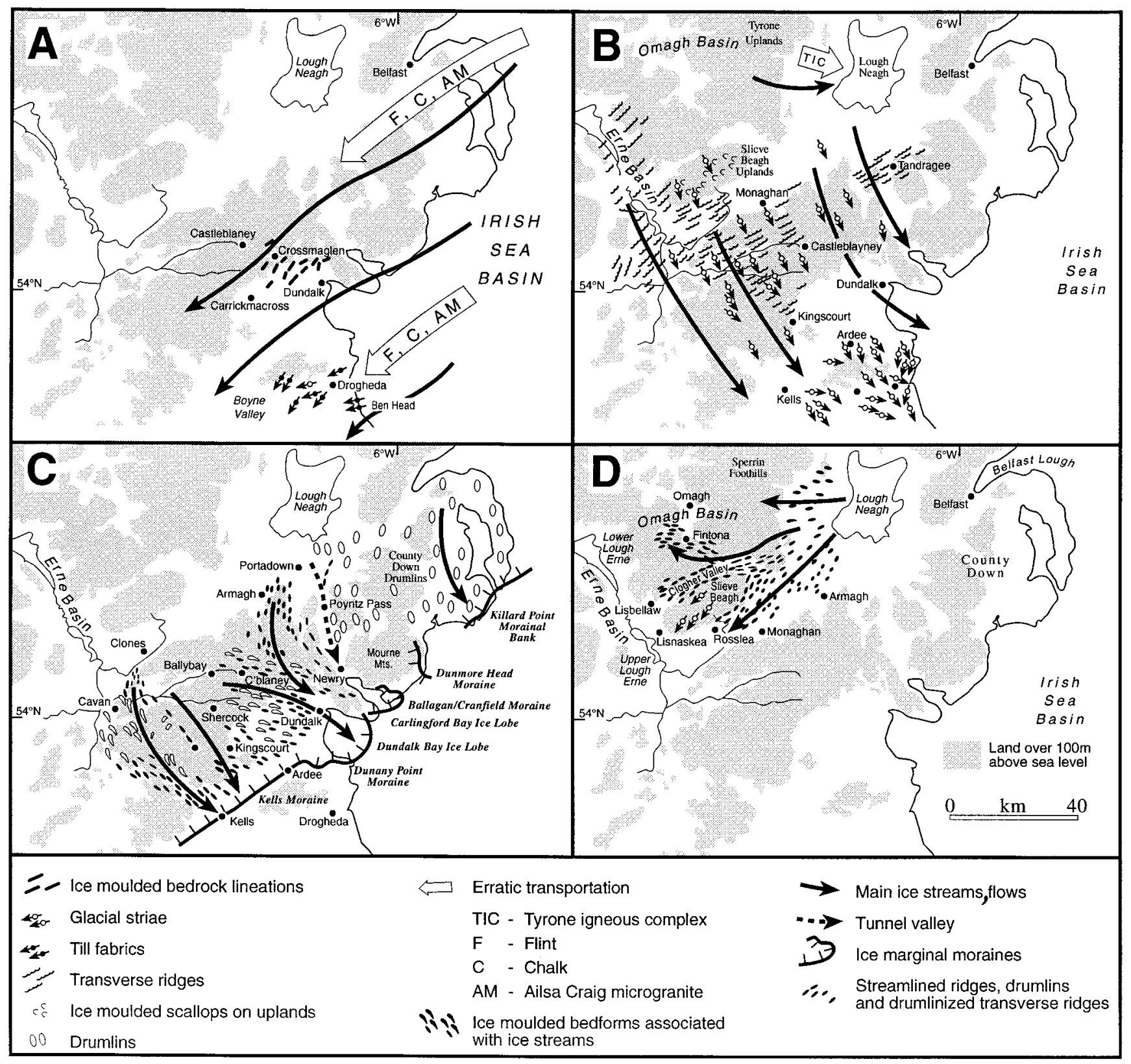

Fig. 3. Summary of areal ice flow patterns and site-specific field evidence used to reconstruct ice-flow stages A-D.

suggests this major ice dispersal centre was located in the Omagh Basin (Fig. 3).

\section{Flow Stage $C$}

This flow stage is recorded by streamlined lineations which overprint the southern and eastern margins of the transverse ridge field of flow stage $\mathrm{B}$. The lineations extend towards the ESE over at least $35 \mathrm{~km}$ to a well-defined frontal moraine complex between Kells and Dundalk Bay (Fig. 3). Flow stage $\mathrm{B}$ ridges have been variously remoulded, streamlined, cross-cut or removed entirely in three main sectors by the action of flow stage $\mathrm{C}$ ice (Fig. 4b).

Around Cavan a funnel-shaped area of streamlined ridges and drumlins narrows northwards into the zone of transverse ridges (Fig. 5). The orientation of ridges and drumlins swings from south to southeast along a curved ice flow arc $60 \mathrm{~km}$ long, terminating at the Kells moraine (Fig. 3). Bedforms within this zone are nearly all streamlined, but comma-shaped bedforms with southward-extended tails are also present and reflect characteristics of the underlying transverse ridge field. In general, the morphological expression of flow stage $\mathrm{C}$ is erosive and marked by bedform cross-cutting, remoulding and streamlining.

A suite of ice-moulded and streamlined bedforms occurs along WNW-ESE ice flow lines around Shercock, Castleblaney and Ballybay (Fig. 5). Non-streamlined (pristine) transverse ridges at Ballybay (ice flow B) are replaced progressively (over $8 \mathrm{~km}$ down-ice distance) by bedforms with a northwest-southeast orientation (Fig. 5). Bedforms along this flowline include transverse ridges with crestline cross-cuts, ridges showing surficial streamlining and sediment carry-over 


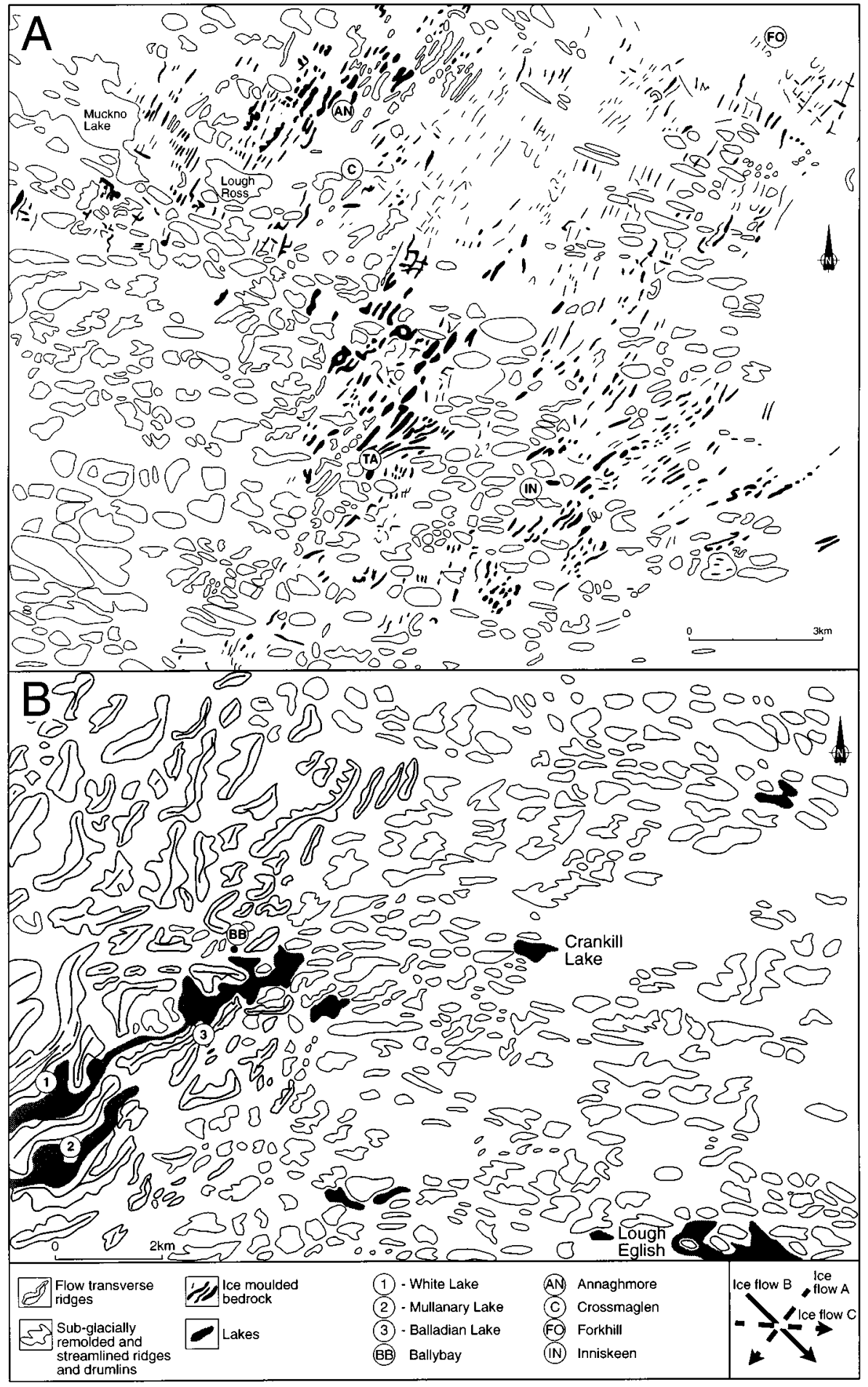

Fig. 4. (a) Sketch of superimposed bedforms in the Crossmaglen area as drawn from Landsat TM imagery. Flow stage $\mathrm{A}$ is represented by bedrock lineaments moulded by a southwesterly ice flow. These bedforms occur stratigraphically below drumlins and streamlined ridges associated with an east-southeasterly ice flow during later ice flow stage C. Areal patterns indicate that bedform overprinting during flow stage $\mathrm{C}$ was stronger and more complete in the western sector of the sketch. (b) Subglacial bedform patterns formed during ice flow stages $\mathrm{B}$ (transverse ridges) and $\mathrm{C}$ (streamlined ridges, drumlins) around Ballybay (BB). Progressive replacement and reshaping of pristine transverse ridges by a continuum of flow-parallel bedforms (see text) occurs ESE from Ballybay. This sequence of landforms developed by erosion during headward propagation of ice streams from the marine-based ice margin in Dundalk Bay (see Fig. 6 for entire regional pattern of ice downdraw). to the ESE, comma-shaped bedforms with hooked tails, incomplete drumlins with truncated leesides similar morphologically to Blattnick moraine (Markgren \& Lassila 1980), asymmetric to symmetric barchanoid forms, and streamlined drumlins of classical, cigar and torpedo shapes (Fig. 4b). The geometry and trend of this bedform suite is clearly associated with east-southeasterly ice flow. This flow event formed a low angle ice lobe centred in Dundalk Bay, and is marked by the Dunany Point moraine (McCabe 1993) (Fig. 3).
A northwest-southeast glacial grain composed of streamlined ridges and drumlins cuts out entirely the northeastsouthwest-trending transverse ridges along a $10 \mathrm{~km}$ wide tract around Keady (Fig. 5). The morphological transition (2-4 km wide) between the two flow signatures is complex and marked by down-ice hooks on ridge margins. This flow line $(70 \mathrm{~km}$ in length), termed the Armagh ice stream, extends from the southern Lough Neagh Basin southwards to limiting moraines in Dundalk Bay (Fig. 3). Ice flow direction changes through a 


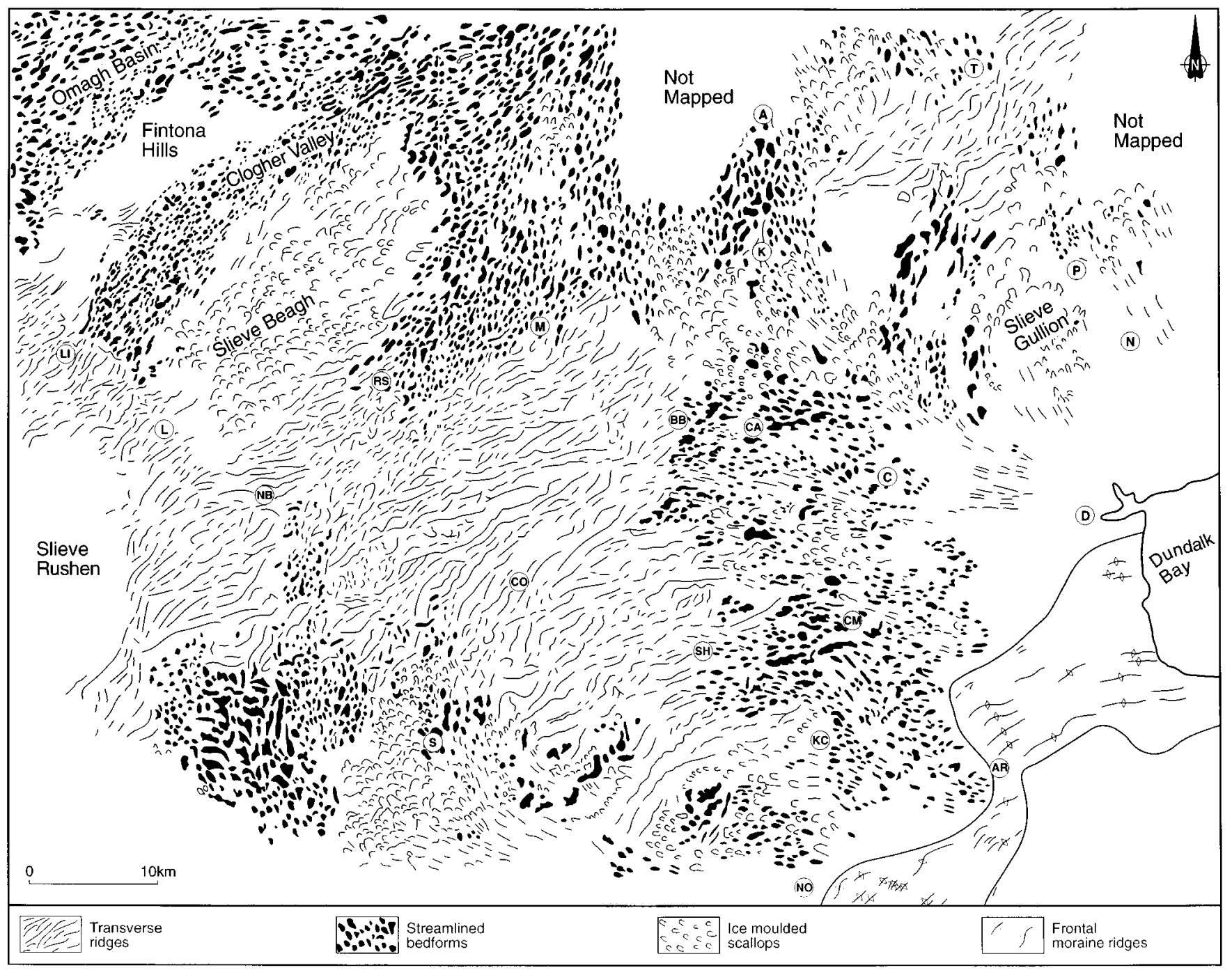

Fig. 5. Distribution of subglacial bedforms in north central Ireland as drawn from Landsat imagery. Note the widespread distribution of northeast-southwest oriented transverse ridges (flow stage B) in lowland areas. Flow stage $\mathrm{C}$ is shown by streamlined bedforms along the eastern and southern margins of the transverse ridges. The Armagh ice stream (flow stage C) cross-cuts the zone of transverse ridges at Keady $(\mathrm{K})$, and is marked by a curved flow line terminating in Dundalk Bay. Flow stage D is represented by the drumlin swarms on either side of the Fintona Hills and Slieve Beagh recording southwesterly ice moulding. See Fig. 3 for schematic summary of ice flows. Abbreviated place names are given in Fig. 2.

$70^{\circ}$ arc from south to east-southeast. Six kilometres north of Crossmaglen the flow line merges with a minor WNW-ESE ice flow line from Castleblaney (Fig. 5) where dissected remnants of transverse ridges are present.

The presence of flow-transverse ridges within the main streamlined sectors suggests strongly that bedform modification and directional overprinting during flow stage $\mathrm{C}$ occurred by net subglacial erosion in specific areas rather than pervasive subglacial deformation beneath the entire ice mass. Down-ice streamlined tails, reflecting sediment remobilization, is best described in terms of a form-process feedback involving erosion of a form obstruction (transverse ridges) with leeside sediment transport and streamlining (process). Pervasive sediment deformation in the sense of Hart \& Boulton (1991) and Hart (1995) cannot explain these distinct morphological field relationships. Bedform geometry and angle of intersection between bedform sets show that each bedform set marks a change in basal ice conditions, possibly from compressive flow regimes associated with transverse ridge formation (Lundqvist 1989) to fast, extending flow associated with sediment streamlining (Patterson \& Hooke 1995). The high basal sediment flux derived from erosion of transverse ridges during flow stage $\mathrm{C}$ is reflected by the presence of moraines at Dunany Point and Kells which mark the limits of flow stage $\mathrm{C}$ ice (Fig. 3). Moraines at the mouth of Carlingford Lough, situated in a similar topographic position to the Dundalk moraines, record the sediment flux associated with drumlinization (sediment streamlining) along the Poyntz Pass tunnel valley (Dardis \& McCabe 1983) (Fig. 3).

The model outlined above can be applied to other bedforms modified during flow stage $\mathrm{C}$ and which possess a significant inherited lineation or internal structure. A drumlin at Kingscourt trends WNW-ESE but is composed internally of large locally-derived bedrock slabs sheared within a deformed matrix (Meehan et al. 1997). Meehan et al. (1997) conclude that shearing and slab emplacement was contemporaneous 


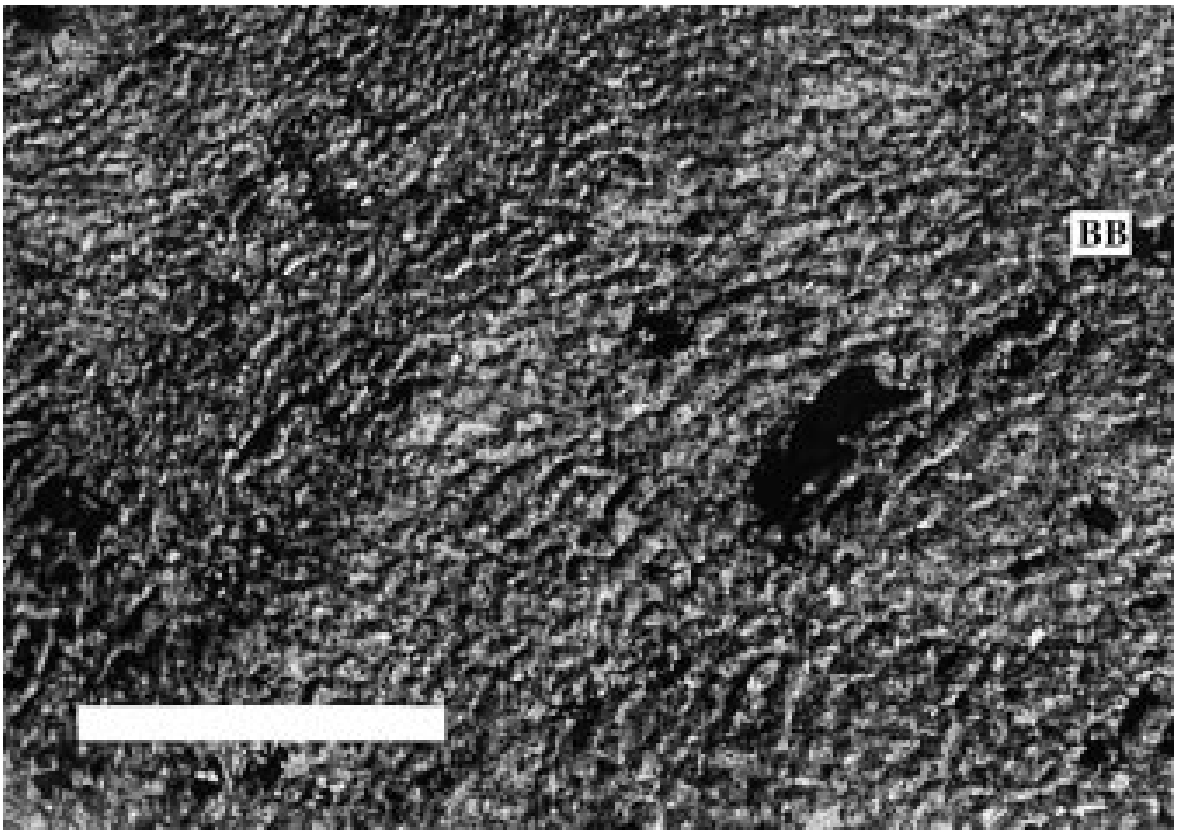

Fig. 6. Landsat image of northeast-southwest-aligned transverse ridges west of Ballybay (BB) formed during flow stage $\mathrm{B}$. Note that ridges provide a distinct northeast-southwest topographic grain to the landscape. Ice moulded bedrock located between drift ridges also records ice pressure and abrasion from northwest to southeast during flow stage B. Scale bar is $10 \mathrm{~km}$.

with drumlinization. However, the location of this drumlin close to the lateral margin of flow stage $\mathrm{C}$ (Fig. 5) suggests that it is a remnant of a flow stage $\mathrm{B}$ ridge which was later streamlined. Furthermore, internal drumlin geometry and shear structures recorded have more in common with compressive processes of transverse ridge formation (Lundqvist 1989) rather than processes of drumlinization (lodgement, debris flow, sheet flow, meltwater activity, meltout) known from the Irish drumlin belt (McCabe \& Dardis 1989).

Bedform modification, overprinting and streamlining occur only along the eastern and southern margins of the transverse ridge field. Bedform morphological patterns, and the absence of streamlining within the main ridge field, suggest that flow stage $\mathrm{C}$ ice involved the headward (northwestward) erosion of ice streams into pre-existing transverse ridges (Fig. 3). This may be related to changes in subglacial thermal regimes as warmer (wet-based) ice headcut into colder (dry-based) ice that preserved the pristine nature of the ridges (Knight \& McCabe 1997b). Convergence of ice flow lines into Dundalk Bay suggests that tidewater calving around the bay periphery, which initiated marine downdraw and propagation of fast ice flow tributaries back into the ice mass, was the main destabilizing mechanism during flow stage $\mathrm{C}$. The most active of the three major ice streams identified (the Armagh ice stream) extended up-ice from Dundalk to the southern Lough Neagh Basin $(70 \mathrm{~km})$ and breached completely the transverse ridge lineations at Armagh and Keady (Fig. 5). This flow event occurred around $14.5 \mathrm{ka} \mathrm{BP}$, as recorded by AMS ${ }^{14} \mathrm{C}$ dating of cold-water microfaunas beneath morainal banks (debris flux of flow stage C) at Dundalk Bay (McCabe 1996; McCabe \& Haynes 1996). Regional flowlines moving directly offshore indicate that the north central Irish Sea Basin was already deglaciated at this time (McCabe 1996).

\section{Flow Stage D}

This stage is recorded by a discrete field of drumlins and streamlined ridges extending westwards from the Lough Neagh Basin into the Clogher Valley and eastern Omagh Basin
(Fig. 5) Northeast-southwest aligned striations on the Slieve Beagh uplands postdate northwest-southeast lineations (flow stage B) and have the same orientation as drumlins in the Clogher Valley and north Monaghan lowlands (Fig. 3). On the southern side of Slieve Beagh the drumlin field resembles a wedge narrowing to the southwest and modifying the transverse ridge morphology. Intersection angles between drumlin long axes and ridge trends are $35-40^{\circ}$. Overall, drumlin alignment shows a northeast-southwest glacial grain distinct from the earlier curved elements resulting from activity of the Armagh ice stream (flow stage C). These flow stages can therefore be clearly distinguished on a stratigraphical basis.

Southwestern margins of the drumlin field around Rosslea and Lisbellaw are not marked by an obvious topographic limit or moraine. It is therefore probable that flow was reactivated during this stage while there was still a large ice mass located in the western lowlands of Lough Erne. A similar ice flow pattern associated with ice dispersal westwards and northwards from the Lough Neagh Basin reached the Sperrin foothills (Dardis 1982) (Fig. 3). Satellite images show that drumlins in this zone contain substantial transverse elements. Unlike the drumlin margins in the Clogher Valley and Monaghan lowlands, the Sperrin foothills show ice-pushed deltaic and glaciofluvial deposits which record ice-marginal positions during retreat (Dardis 1982). Their morphological characteristics and locations indicate that the main Sperrin Mountain peaks were already deglaciated at this time. The radial pattern of ice flow from the Lough Neagh Basin is consistent with renewed ice mass activity associated with drumlinization, and records the final oscillations of lowland ice masses in north central Ireland.

\section{Chronology and significance of ice flow stages A-D}

The relative age and extent of the flow stages identified in north central Ireland is shown in Fig. 3. Only flow stage C can be effectively time-constrained by AMS ${ }^{14} \mathrm{C}$ dates from in situ marine microfaunas from Dundalk Bay. Here, the stratigraphy records open marine conditions at $15-16 \mathrm{ka}$ BP immediately prior to the formation of terminal moraines (McCabe 1996; 

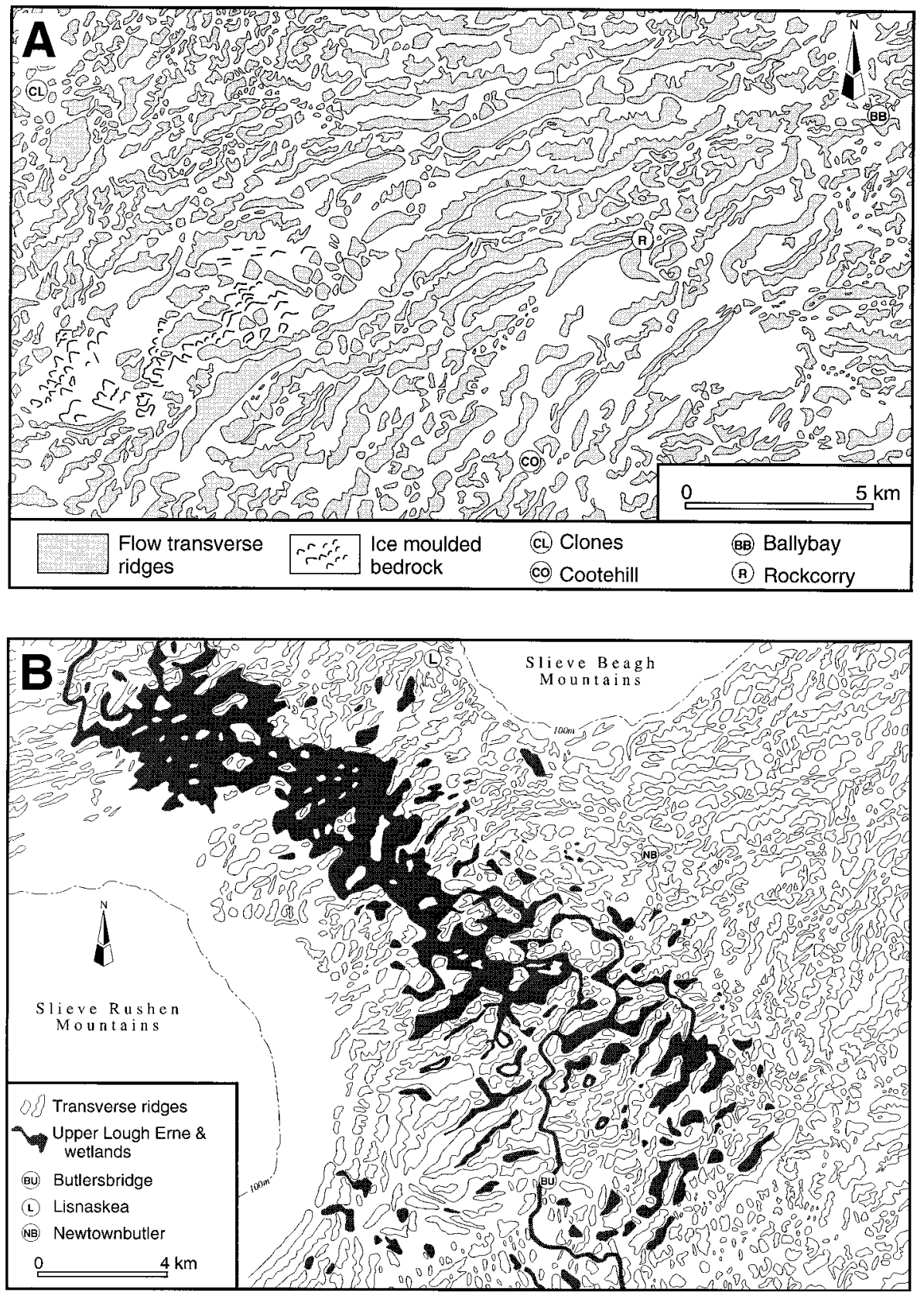

Fig. 7. (a) Pattern of flow-transverse ridges around Ballybay. Ridge orientation is unrelated to bedrock strike. (b) Pattern of flow-transverse ridges in the Upper Lough Erne Basin. Lake and wetland boundaries are determined by the disposition of the transverse ridges. Ridges also lie contour-parallel around Slieve Rushen and Slieve Beagh.
McCabe \& Haynes 1996; McCabe \& Clark 1998). Morphological evidence shows that these moraines mark ice limits synchronous with the highest regional late-glacial raised beaches (Stephens \& McCabe 1977).

Flow stage D represents the last major ice oscillation identified in north central Ireland because it stratigraphically overprints all other bedform sets. Flow stage D streamlining, contained entirely beneath the ice mass, did not propagate to, and was therefore not generated at, ice margins. This contrasts strongly with flow stage $\mathrm{C}$ ice streams which propagated into the ice mass from marine margins. Therefore drumlinization during flow stage $\mathrm{D}$ may reflect a change in subglacial thermal regimes (pore water pressure) or renewed ice mass activity unrelated to events at the ice-margin. Flow stage D cannot be dated directly but it must postdate $14.5 \mathrm{ka} \mathrm{BP}$, the age of flow stage $\mathrm{C}$, and predate the Younger Dryas event (c. 11-10 ka BP) which was restricted to small cirque glaciers in Ireland (Colhoun \& Synge 1980; Gray \& Coxon 1991). These arguments, together with the strong coupling between ice mass activity and ocean-atmospheric circulation (Broecker \& Denton 1989), suggest that flow stage D may be correlated with a phase of ice mass activity, possibly around $13.5 \mathrm{ka} \mathrm{BP}$ (McCabe 1996).

Scale and continuity of flow stage B flow lines suggests correlation with the last major glacial advance of Irish ice southeastwards into the Irish Sea Basin (Fig. 3) (Synge \& Stephens 1960; McCabe 1987; Eyles \& McCabe 1989). According to dates of other European glacial maxima (Bowen 1994; Sejrup et al. 1994) this flow stage may have occurred around $22-25 \mathrm{ka}$ BP. However, it is unlikely that transverse ridge formation occurred during maximum glacial conditions, but may have postdated it during a period of bed warming and 
sediment reorganization behind the ice margin (cf. Bouchard 1989). This reorganization, and associated changes in subglacial thermal regime and water availability, is supported by the absence of streamlining of the many transverse ridge crests which suggests the ridges were preserved beneath cold and dry-based ice.

Amino acid assessment of marine mollusc fragments from the 'shelly tills' of east central Ireland suggests that they date from the Devensian (Bowen 1994), which therefore places flow stage A within the last glacial cycle predating the glacial maximum.

Millennial-scale ice mass variability appears to have been characteristic of amphi-North Atlantic ice masses during the late Devensian (Bowen 1994; Dansgaard et al. 1993; Broecker 1994; Bond \& Lotti 1995; Fronval et al. 1995). Ice oscillations in the British Isles have also been documented (McCabe 1996). Geological evidence from north central Ireland suggests that flow stages $\mathrm{A}-\mathrm{D}$, belonging to the last glacial cycle, record phases of ice buildup and advance (flow stages A, B) followed by more complex oscillations during later ice decay (flow stages $\mathrm{C}, \mathrm{D})$.

\section{Concluding remarks}

Field evidence from north central Ireland demonstrates that bedform relationships are a powerful tool in mid-latitude ice mass reconstructions (e.g. Boulton \& Clark 1990) and reflect rapid environmental changes in the sensitive northeastern Atlantic (McCabe 1996). The proposed ice flow stages offlap northwards and record complex changes in ice mass energy levels and geomorphological activity.

Conclusions from detailed field data focus on three topical aspects of glacial geology critical to interpretations of ice mass mobility.

(1) The role of subglacial sediment deformation in ice mass dynamics and bedform development is an unsolved problem. Some models (Boulton \& Clark 1990) suggest that subglacial sediments, which eventually form drumlins, are transported and deposited as mobile masses (Boulton 1987). However, a wide range of sedimentary structures observed within undeformed layer-cake successions in the Irish drumlin belt do not support this idea (Dardis \& McCabe 1983; McCabe 1993). Evidence in north central Ireland suggests that subglacial sediment deformation is not the main mechanism leading to ice mass variability, and that bedform cross-cutting and erosion can be generated both external to (flow stage C) and within the ice mass (flow stage D). The presence of variably nonstreamlined, cross-cut and overprinted flow-transverse ridges does not attest to regional-scale deformation which would have destroyed older bedform sets. Satellite imagery and field evidence support a net-erosional origin for drumlins around Castleblaney and Crossmaglen through the reorganization of pre-existing sediments (Fig. 4b). In addition, the drumlin field of County Down (area of $1600 \mathrm{~km}^{2}$ ) is developed in Silurian shales and greywackes. This suggests that current ideas concerning the role of subglacial deformation as a drumlinforming process and as an input into glacial models need to be re-examined.

(2) Models depicting regular geomorphological zones outward from ice dispersal centres (e.g. Aario 1977; Shilts et al. 1987; Bouchard 1989; Menzies \& Shilts 1996) may not represent either sequential bedform sets or time-transgressive bedform formation. Bedforms are composite, are a response to ice mass variability, and may overprint the geomorphological or sedimentary signatures of older bedforms. This study suggests that bedform transitions are the geomorphological expression of down-ice changes in subglacial processes and environments, coupled to regional-scale shifts in ice centres and the location of ice margins.

(3) Some current glacial models assume fast ice flow is related to ice mass buildup and decay alone (e.g. MacAyeal 1993) but marine downdraw can induce headward propagation of ice streams and massive ice loss, as during flow stage $\mathrm{C}$ in north central Ireland. Discrete drumlin fields around the Irish Sea Basin margins in England, Scotland and Ireland may reflect either marine downdraw alone or a combination of ice readvance and downdraw (Eyles \& McCabe 1989). Trigger mechanisms of drumlinization therefore require more detailed field observations. Sediment sequences and bedform relationships in the Irish Sea Basin region could provide a suitable testing-ground for these ideas because of its location in the sensitive northeastern Atlantic (McCabe 1996) and the possible role of Atlantic-wide climate events such as Heinrich event 1 (McCabe \& Clark 1998).

K. McDaid and M. Millar are thanked for drawing the diagrams, and N. McDowell for photography. Some of this work was supported by a DENI CAST award (to J.K.).

\section{References}

Aario, R. 1977. Flutings, drumlins and Rogen-landforms. Nordia, 2, 5-14.

Bond, G.C. \& LotTI, R. 1995. Iceberg discharges into the North Atlantic on millenial time scales during the last deglaciation. Science, 267, 1005-1010.

Bouchard, M.A. 1989. Subglacial landforms and deposits in central and northern Québec, Canada, with emphasis on Rogen moraines. Sedimentary Geology, 62, 293-308

Boulton, G.S. 1987. A theory of drumlin formation by subglacial sediment deformation. In: Menzies, J. \& Rose, J. (eds) Drumlin Symposium. Balkema, Rotterdam, 25-80.

— \& ClARK, C.D. 1990. A highly mobile Laurentide ice sheet revealed by satellite images of glacial lineations. Nature, 346, 813-817.

—, Jones, A.S., Clayton, K.M. \& Kenning, M.J. 1977. A British icesheet model and patterns of glacial erosion and deposition in Britain. In: Shotton, F.W. (ed.) British Quaternary Studies-recent advances. Clarendon Press, Oxford, 231-246.

Bowen, D.Q. 1994. The Pleistocene of north west Europe. Science Progress Oxford, 76, 209-223.

- Rose, J., McCabe, A.M. \& Sutherland, D.G. 1986. Correlation of Quaternary glaciations in England, Ireland, Scotland and Wales. Quaternary Science Reviews, 5, 299-340.

BROECKER, W.S. 1994. Massive iceberg discharges as triggers for global climate change. Nature, 372, 421-424.

— \& Denton, G.H. 1989. The role of ocean-atmosphere reorganizations in glacial cycles. Geochimica et Cosmochimica Acta, 53, 2465-2501.

Charlesworth, J.K. 1939. Some observations on the glaciation of north-east Ireland. Proceedings of the Royal Irish Academy, 45B, 255-295.

Clark, C.D. 1993. Mega-scale glacial lineations and cross-cutting ice-flow landforms. Earth Surface Processes and Landforms, 18, 1-29.

Colmoun, E.A. \& Synge, F.M. 1980. The cirque moraines at Lough Nahanagan, County Wicklow, Ireland. Proceedings of the Royal Irish Academy, 80B, 25-45.

Dansgaard, W., Johnsen, S.J., Clausen, H.B., Dahl-Jensen, D., Gundestrup, N.S., Hammer, C.U., Hvidberg, C.S., Steffensen, J.P., Sveinbjörnsdottir, A.E., Jouzel, J. \& Bond, G. 1993. Evidence for general instability of past climate from a $250-\mathrm{kyr}$ ice-core record. Nature, 364, 218-220.

DARDIS, G.F. 1982. Sedimentological aspects of the Quaternary geology of south-central Ulster, Northern Ireland. PhD Thesis, Ulster Polytechnic, Jordanstown.

— \& McCABE, A.M. 1983. Facies of subglacial channel sedimentation in late-Pleistocene drumlins, Northern Ireland. Boreas, 12, 263-278. 
DWerryhouse, A.R. 1923. The glaciation of north-eastern Ireland. Quarterly Journal of the Geological Society of London, 79, 352-421.

Eyles, N. \& McCabe, A.M. 1989. The Late Devensian (<22,000 BP) Irish Sea Basin: the sedimentary record of a collapsed ice sheet margin. Quaternary Science Reviews, 8, 307-351.

Fisher, T.G. \& Shaw, J. 1992. A depositional model for Rogen moraine, with examples from the Avalon Peninsula, Newfoundland. Canadian Journal of Earth Sciences, 29, 669-686.

Fronval, T., Jansen, E., Bloemendal, J. \& Johnsen, S. 1995. Oceanic evidence for coherent fluctuations in Fennoscandian and Laurentide ice sheets on millennium timescales. Nature, 374, 443-446.

Gray, J.M. \& Coxon, P. 1991. The Loch Lomond Stadial glaciation in Britain and Ireland. In: Ehlers, J., Gibbard, P.L. \& Rose, J. (eds) Glacial deposits in Great Britain and Ireland. Balkema, Rotterdam, 89-105.

HART, J.K. 1995. Subglacial erosion, deposition and deformation associated with deformable beds. Progress in Physical Geography, 19, 173-191.

\& Boulton, G.S. 1991. The interrelation of glaciotectonic and glaciodepositional processes within the glacial environment. Quaternary Science Reviews, 10, 335-350.

KNight, J. \& McCABE, A.M. 1997a. Drumlin evolution and ice sheet oscillations along the NE Atlantic margin, Donegal Bay, western Ireland. Sedimentary Geology, 111, 57-72.

_ \& 1997b. Identification and significance of ice-flow-transverse subglacial ridges (Rogen moraines) in north central Ireland. Journal of Quaternary Science, 12, 519-524.

LundQvist, J. 1969. Problems of the so-called Rogen moraine. Sveriges Geologiska Undersökning, 648, 1-32.

1989. Rogen (ribbed) moraine-identification and possible origin. Sedimentary Geology, 62, 281-292.

MacAyeal, D.R. 1993. Binge/purge oscillations of the Laurentide Ice Sheet as a cause of the North Atlantic's Heinrich events. Paleoceanography, 8, 775784.

Manabe, S. \& Stouffer, R.J. 1995. Simulation of abrupt climate change induced by freshwater input to the North Atlantic Ocean. Nature, 378, 165-167.

Markgren, M. \& Lassila, M. 1980. Problems of Rogen moraine morphology: Rogen moraine and Blattnick moraine. Boreas, 9, 271-274.

MCCABE, A.M. 1969. The glacial deposits of the Maguiresbridge area, County Fermanagh, Northern Ireland. Irish Geography, 6, 63-77.

- 1972. Directions of Late-Pleistocene ice-flows in Eastern Cos. Meath and Louth, Ireland. Irish Geography, 6, 443-461.

1973. The glacial stratigraphy of eastern Counties Meath and Louth Proceedings of the Royal Irish Academy, 73B, 355-382.
— 1987. Quaternary deposits and glacial stratigraphy in Ireland. Quaternary Science Reviews, 6, 259-299.

— 1993. The 1992 Farrington Lecture: Drumlin bedforms and related ice-marginal depositional systems in Ireland. Irish Geography, 26, 22-44.

1996. Dating and rhythmicity from the last deglacial cycle in the British Isles. Journal of the Geological Society, London, 153, 499-502.

— \& Clark, P.U. 1998. Amphi-North Atlantic ice-sheet variability during Heinrich event 1. Nature, 392, 373-377.

\& DARDIS, G.F. 1989. A geological view of drumlins in Ireland. Quaternary Science Reviews, 8, 169-177.

_ \& HAYNES, J.R. 1996. A Late Pleistocene intertidal boulder pavement from an isostatically emergent coast, Dundalk Bay, eastern Ireland. Earth Surface Processes and Landforms, 21, 555-572.

Meehan, R.T., Warren, W.P. \& Gallagher, C.J.D. 1997. The sedimentology of a Late Pleistocene drumlin near Kingscourt, Ireland. Sedimentary Geology, 111, 91-105.

Menzies, J. \& Shilts, W.W. 1996. Subglacial environments. In: Menzies, J. (ed.) Past Glacial Environments; Sediments, forms and techniques. ButterworthHeineman, Oxford, 15-136.

Patterson, C.J. \& Hooke, R.LeB. 1995. Physical environment of drumlin formation. Journal of Glaciology, 41, 30-38.

Punkari, M. 1985. Glacial geomorphology and dynamics in Soviet Karelia interpreted by means of satellite imagery. Fennia, 163, 113-153.

_ 1993. Modelling of the dynamics of the Scandinavian Ice Sheet using remote sensing and GIS methods. In: ABER, J.S. (ed.) Glaciotectonics and Mapping Glacial Deposits. Canadian Plains Research Center, University of Regina, 232-250.

Sejrup, H.P., Haflidason, H., Aarseth, I., King, E., Forsberg, F., Long, D. \& Rokoengen, K. 1994. Late Weichselian glaciation history of the northern North Sea. Boreas, 23, 1-13.

Shilts, W.W., Aylesworth, J.M., Kaszycki, C.A. \& Klassen, R.A. 1987. Canadian Shield. In: Graf, W.L. (ed.) Geomorphic Systems of North America. Geological Society of America Centennial Special Volumes, 2, 119-161.

StePhens, N. \& MCCABE, A.M. 1977. Late-Pleistocene ice movements and patterns of Late- and Post-Glacial shorelines on the coast of Ulster, Ireland. In: Kidson, C. \& ToOLEy, M.J. (eds) The Quaternary History of the Irish Sea. Seal House Press, Liverpool, 179-198.

Synge, F.M. \& StePhens, N. 1960. The Quaternary period in Ireland-an assessment, 1960. Irish Geography, 4, 121-130.

WARREN, W.P. 1992. Drumlin orientation and the pattern of glaciation in Ireland. Sveriges Geologiska Undersökning, 81, 359-366. 